\title{
Sprawozdanie z Ogólnopolskiej Konferencji Naukowej „Nauka i praktyka w służbie człowiekowi pracy: "Inspekcja Pracy - wyzwania przyszłości»", Wydział Prawa i Administracji Uniwersytetu im. Adama Mickiewicza w Poznaniu, 27 października 2016 r.
}

W dniu 27 października 2016 r. na Wydziale Prawa i Administracji UAM miała miejsce konferencja naukowa pt. „Nauka i praktyka w służbie człowiekowi pracy: «Inspekcja Pracy - wyzwania przyszłości»", zorganizowana przez WPiA i Państwową Inspekcję Pracy. Wspólna inicjatywa jest wynikiem podpisania 10 marca 2016 r. deklaracji o współpracy pomiędzy WPiA UAM a Okręgowym Inspektoratem Pracy w Poznaniu. Patronat honorowy nad konferencją objęli Rektor UAM prof. UAM dr hab. Andrzej Lesicki oraz Główny Inspektor Pracy Roman Giedrojć. Wydarzenie to było pierwszym z cyklu Ogólnopolskich Konferencji Naukowych "Nauka i praktyka w służbie człowiekowi pracy", a wzięło w nim udział blisko 130 naukowców i praktyków z całego kraju.

Konferencja została podzielona na dwie części. W pierwszej z nich znalazły się wystąpienia wybitnych przedstawicieli nauki oraz praktyków z Inspekcji Pracy dotyczące uprawnień, zadań oraz zakresu działania Państwowej Inspekcji Pracy, także w ujęciu historycznym. Swoje referaty wygłosili: Główny Inspektor Pracy Roman Giedrojć, Nadinspektor Pracy Tomasz Kozłowski, prof. dr hab. Arkadiusz Sobczyk z Uniwersytetu Jagiellońskiego oraz dr hab. Anna Musiała z Uniwersytetu im. Adama Mickiewicza w Poznaniu. Natomiast w drugiej części wydarzenia miała miejsce dyskusja z udziałem zaproszonych gości, która była kontynuowana także po przerwie. W tej części padały również pytania z sali, na które odpowiadali dyskutanci.

Głównym celem, który przyświecał organizatorom konferencji, było omówienie roli i miejsca Państwowej Inspekcji Pracy w systemie ochrony pracy w Polsce. Jest to zagadnienie niezwykle istotne, zwłaszcza w kontekście częstych i dynamicznych zmian w zakresie samego prawa pracy, którego częścią jest owa ochrona. Właśnie z tychże zmian wynika konieczność bliższego przyjrzenia się zadaniom oraz wyzwaniom stawianym Państwowej Inspekcji Pracy, na którą to prawodawca nakłada coraz szerszy zakres zadań i obowiązków.

Licznie przybyłych gości oraz prelegentów przywitała dr hab. Anna Musiała, która jest jednym z głównych inicjatorów współpracy WPiA z Państwową Inspekcją Pracy. Następnie oddała ona głos prof. UAM dr. hab. Tadeuszowi Wallasowi - prorektorowi ds. kadry i finansów UAM, który w krótkim przemówieniu zwrócił uwagę 
na duże znaczenie związków nauki z praktyką w zakresie ochrony praw pracowniczych i działań podejmowanych w związku z tą ochroną. Na te same aspekty wskazał prof. zw. dr hab. Roman Budzinowski, dziekan WPiA UAM, który wyraził duże zadowolenie z podpisania deklaracji o współpracy z Państwową Inspekcją Pracy i możliwości goszczenia na Wydziale tak dużej rzeszy osób zainteresowanych tematyką ochrony pracy. Następnie głos zabrała Stanisława Ziółkowska, Okręgowy Inspektor Pracy w Poznaniu, która również podkreśliła znaczenie współpracy Inspekcji Pracy ze środowiskiem akademickim oraz możliwość wspólnego działania $\mathrm{w}$ celu propagowania istotnych kwestii związanych $\mathrm{z}$ ochroną człowieka w procesie pracy. Zwróciła także uwagę zgromadzonych na to, że jest to dopiero początek intensywnej współpracy, a odbywająca się konferencja to pierwsze z cyklu ogólnopolskich spotkań praktyków i przedstawicieli nauki dotyczących tej ważkiej tematyki.

Pierwszym z prelegentów był Nadinspektor Pracy Tomasz Kozłowski. W swoim wystąpieniu przedstawił historię Państwowej Inspekcji Pracy w Polsce, dużo miejsca poświęcając opisaniu sytuacji geopolitycznej towarzyszącej powstaniu tej instytucji. Zgromadzeni goście dowiedzieli się, że mimo iż od blisko stu lat istnienia Inspekcji Pracy w naszym kraju niejednokrotnie zmieniały się rządy, struktury i sposób jej podporządkowania, to niezmiennie najważniejszą misją tego organu pozostaje nadzorowanie należytego stosowania przepisów o ochronie pracy. Nadinspektor zaakcentował także szeroki zakres uprawnień inspektorów pracy od początków powstania Inspekcji, dodając jednocześnie, że obecnie można zaobserwować rosnącą tendencję do ciągłego zwiększania tychże uprawnień.

Następnie swoje przemówienie wygłosił Główny Inspektor Pracy Roman Giedrojć, który skupił się na zadaniach i wyzwaniach XXI w. stawianych Inspekcji Pracy. Wskazał on aktualne umiejscowienie, zadania, uprawnienia i rolę Państwowej Inspekcji Pracy w strukturze organów kontroli nad warunkami pracy. Podobnie jak przedmówca, zwrócił uwagę na ciągłe zwiększanie zakresu uprawnień i obowiązków inspektorów i związane z tym zagrożenia. W swoim wystąpieniu wskazał na zmieniające się prawo i konieczność dostosowywania zadań inspektorów do nowych warunków, co nie zawsze jest łatwe.

Trzeci referat przedstawił prof. dr hab. Arkadiusz Sobczyk z Uniwersytetu Jagiellońskiego. Jego wystąpienie dotyczyło ukształtowania systemu ochrony pracy w Polsce i umiejscowienia Państwowej Inspekcji Pracy w tym systemie. Wskazał także naczelny cel, dla którego powołana została Inspekcja, tj. nadzór i kontrolę przestrzegania prawa pracy. Zaznaczył, że obecnie inspektorzy, chcąc realizować cel główny, często napotykają problemy wynikające z tego, że ustawodawca nakłada na nich coraz więcej innych, absorbujących czas obowiązków.

Ostatni referat w pierwszej części konferencji wygłosiła dr hab. Anna Musiała z UAM w Poznaniu, która przedstawiła zakres kontroli Państwowej Inspekcji Pracy w świetle konwencji Międzynarodowej Organizacji Pracy. Jej wystąpienie dotyczyło istotnych kwestii związanych z możliwością przeprowadzania przez organy Inspekcji kontroli w sposób niezapowiedziany u wszystkich przedsiębiorców oraz tego, czy w takiej sytuacji należy stosować przepisy ustawy o swobodzie działalności gospodarczej. Prelegentka wskazała na niejednolite orzecznictwo w omawianym zakresie oraz na niską skuteczność przeprowadzanych kontroli, będącą konsekwencją praktyki informowania o zamiarze ich przeprowadzenia. 
W drugiej części konferencji miał miejsce panel dyskusyjny z udziałem zaproszonych praktyków oraz przedstawicieli nauki z różnych części kraju. Dyskusję moderowała dr hab. Anna Musiała z UAM w Poznaniu, a udział w niej wzięli: Roman Giedrojć - Główny Inspektor Pracy, Halina Tulwin - dyrektor Departamentu Prawnego Głównej Inspekcji Pracy, Krzysztof Kowalik - dyrektor Departamentu Nadzoru i Kontroli Głównej Inspekcji Pracy, Jarosław Leśniewski - dyrektor Departamentu Legalności Zatrudnienia Głównej Inspekcji Pracy, Stanisława Ziółkowska - Okręgowy Inspektor Pracy w Poznaniu, Tomasz Gajdziński - zastępca Okręgowego Inspektora Pracy w Poznaniu, dr Aleksandra Bocheńska z Uniwersytetu im. Adama Mickiewicza w Poznaniu, dr Dariusz Makowski z Uniwersytetu Łódzkiego, prof. dr hab. Arkadiusz Sobczyk z Uniwersytetu Jagiellońskiego, dr hab. Krzysztof Walczak z Uniwersytetu Warszawskiego oraz Barbara Surdykowska z NSZZ „Solidarność". Rozważania dyskutantów koncentrowały się wokół kwestii poruszonych w wystąpieniach zaprezentowanych w części pierwszej konferencji. Po raz kolejny podkreślono niezwykle ważną rolę, jaką pełni Państwowa Inspekcja Pracy w zakresie ochrony człowieka w procesie pracy. Niejednokrotnie wskazywano na szeroki zakres zadań inspektorów oraz na fakt, że zakres ten wciąż wzrasta, co może negatywnie wpływać na realizację głównego celu, dla którego Inspekcja została powołana. Dyskutanci rozmawiali także na temat jakości regulacji prawnych dotyczących Inspekcji oraz tego, co należałoby w owych regulacjach zmienić, aby zapewnić najwyższy standard realizacji ochrony pracy w Polsce. Podczas rozmowy wskazano na konieczność uchwalenia przepisów jasnych i precyzyjnych, niebudzących wątpliwości w ich stosowaniu, gdyż obowiązujące obecnie powoduja, że skuteczność realizacji zadań Inspekcji jest znacząco ograniczona.

W tej części spotkania padały również pytania gości z sali, na które odpowiadali dyskutanci. Pytania koncentrowały się wokół tematyki konferencji i dotyczyły m.in. zakresu zadań Państwowej Inspekcji Pracy oraz realnych możliwości wykonywania ich przez inspektorów. Jeden z gości nawiązał do aspektów historycznych i przedstawił okoliczności, w jakich było dane pracować inspektorom w okresie przed transformacją ustrojową.

Reasumując, konferencja zorganizowana przez Wydział Prawa i Administracji UAM oraz Państwową Inspekcję Pracy stała się miejscem dyskusji teoretyków i praktyków zajmujących się ochroną pracy. Niewątpliwie, poruszone zagadnienia mają istotne znaczenie i wpływ na życie każdego człowieka, ponieważ dotyczą niezwykle ważkiej problematyki związanej z pracą. Uczestnicy zgodnie uznali, że tego typu spotkania są potrzebne, gdyż pozwalają dzielić się doświadczeniami. Na zakończenie konferencji dr hab. Anna Musiała zaprosiła wszystkich obecnych na kolejne spotkanie z cyklu "Nauka i praktyka w służbie człowiekowi pracy”, które zostanie zorganizowane w listopadzie 2017 r., a dotyczyć będzie ważnego i często w ostatnim czasie poruszanego tematu umów na czas określony. Podsumowaniem przeprowadzonej konferencji będzie monografia, w której znajdą się referaty prelegentów oraz artykuły osób zainteresowanych i na co dzień zajmujących się zagadnieniami omówionymi podczas spotkania. 